Vikki C. Terrile

\title{
The display's the thing
}

\section{A successful interactive, analog community college library display}

O

ne of the first things you see when you enter the Kurt R. Schmeller Library on the Queensborough Community College campus are three display cases arranged in a horseshoe, accented with a poster display case on a stand. This prime floor space often serves as a waiting space as students read their texts or wait for friends to join them in the library. Historically, the displays featured rotated content, generally heritage months and other used with permission.

broad topics,

with the cases packed full of books (in varying states of repair and condition), artifacts, and matted description and information labels and captions. According to everyone, the displays were routinely ignored.

When the question was posed to the department about who would take over the displays following a retirement, I volunteered. I started simply. My first display in fall 2018 focused on our Common Read book for the 2018-2019 academic year, The Good Food Revolution by Will Allen (with Charles Wilson). It seemed a natural fit for the time of year-I used artificial fall foliage from craft and dollar stores; children's play fruit and vegetables; books from our collection on urban agriculture, the Great Diaspora, and nutrition; and photos and infographics. Yards of fabric printed with vegetables were used to line the two horizontal cases and the bottom of the vertical case. It was a nice display. My colleagues complimented me on it, noting the relative sparsity of my style, if somewhat tonguein - cheek. The students continued to ignore it.

W i t h no assigned schedule for how frequently I needed to change out the display cases, I waited for inspiration to hit. As the end of the fall semester and the calendar year approached, and with the final season of Game of Thrones on the horizon, I toyed with doing a "winter is coming" display that could include the books from the series, anything related to winter

Vikki C. Terrile is assistant professor, public services and assessment librarian at Queensborough Community College-CUNY in Bayside, New York, email: vterrile@ qcc.cuny.edu

๑) 2021 Vikki C. Terrile 
or weather (and, of course, dragons), only to discover we didn't own any of the $A$ Song of Ice and Fire books. Another idea for a graphic novel/comic book display was stymied for the same reason. ${ }^{1}$

But thinking about books and media led me to think about the many books being made into movies and television series, and how this was a natural goldmine for a display. Variations of "Page to Screen" are fairly easy displays to put together (as Pinterest clearly indicates), and mine was no exception. For this second display, I purchased movie-related props, including clapperboards, popcorn tubs, a long banner meant to be hung from the ceiling that looked like a gigantic filmstrip and included dangling stars, cameras, and film reels, and, of course, a "red carpet" to line the cases.

To stick with the movie theme, I printed and assembled

life-sized vintage boxes of popular movie theater candy (Goobers, Raisinets, $\mathrm{J} \mathrm{u} \mathrm{n} \mathrm{i} \mathrm{o} \mathrm{r}$ Mints), and found glitter foam stars and shiny silver wrapping paper at a local dollar store. To simulate

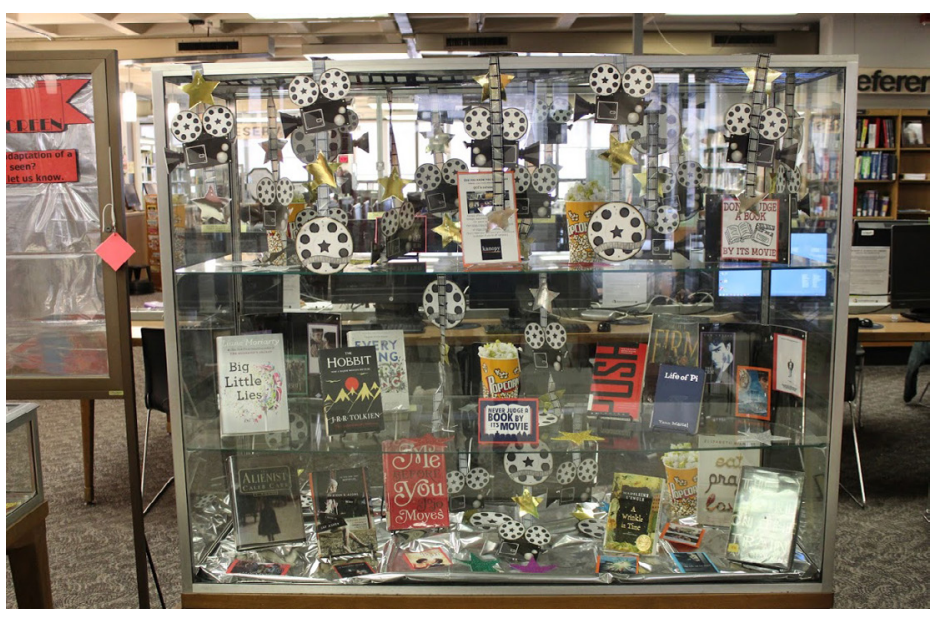

Page to Screen Display, QCC Library. Photo by Lawrence Chan, used with permission.

popcorn, I glued tiny balls of yellow and white tissue onto bunched paper stuffed in the popcorn tubs. This trick from Pinterest proved so realistic it fooled a number of people and also caused me to reach absentmindedly for a handful while I was assembling the containers.

For this display, I knew I wanted to use the tops of the horizontal cases to showcase books our students could check out. All of the books displayed in the cases were items of which we own multiple copies. Also for the books inside the cases, I printed a small, color version of the official movie or television show publicity poster and mounted these to cardstock to display near the book. Finally, printed images that stated "the book was better" and to "never judge a book by its movie" were also added to the display, along with larger placards describing how to access our library's subscription to the Kanopy streaming video service.

Besides having books available for circulation in the exhibit, I decided I wanted to make the whole thing at least somewhat interactive. I used the standing poster case to pose the question "What's the best screen adaptation of a book you've ever seen?" and hung a pad of sticky notes from the case to write and post their answers. I got the ball rolling with my own favorite (To Kill a Mockingbird) and gradually, the sticky notes accumulated, with a total of 19 responses by the time I changed the display three months later. The response to the "Page to Screen" display was extraordinary. The chair of the library emailed the campus community about it, and our interim president made a special trip over to see it and emailed me with his compliments. Faculty and staff within and without the library department raved, and the 12 or so book stands on the top of the display needed regular replenishing.

I had multiple goals for the "Page to Screen" display: I wanted to showcase books for recreational reading, many of which may be harder to find in our LC-cataloged collection than if they were in our Leisure Reading collection or in public library collections. I also wanted to create a display that was "fun" and visually interesting. My first display had been pretty but kind of a snoozer, and the comments I had heard about my predecessors' displays hinted at a history of boring, pedantic exhibits that did not interest the students. Given that we average 1,405 visits a day, while also dealing with the declining circulation facing most academic libraries, I wanted to create something that would attract student interest in those crucial first 


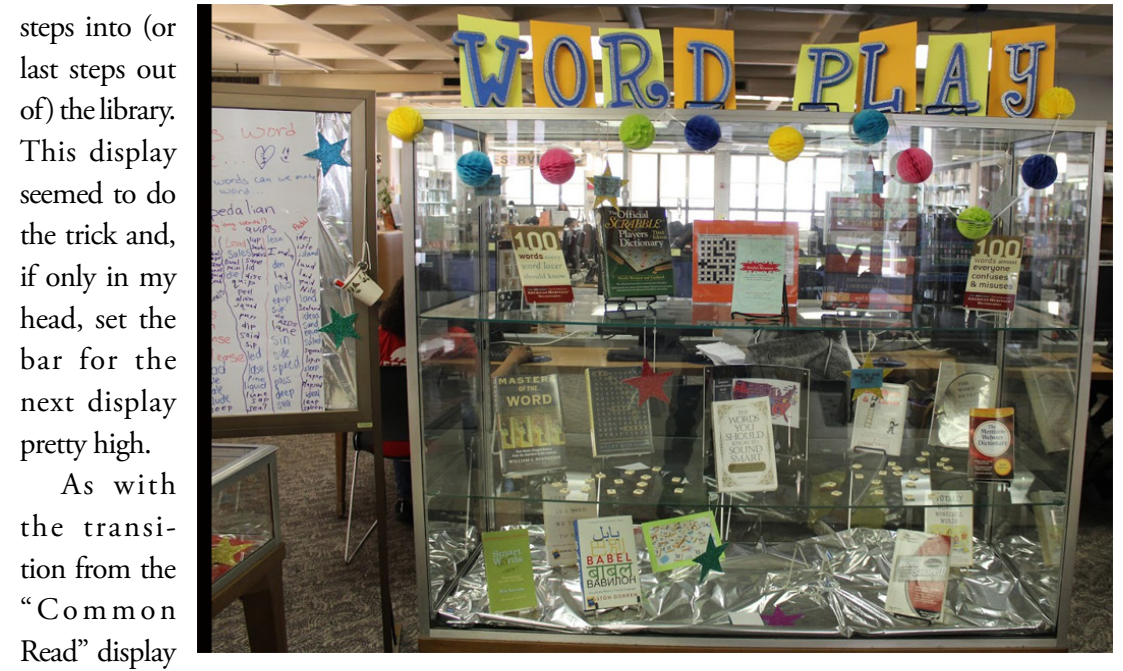

to the "Page Word Play Display, QCC Library. Photo by Lawrence Chan, used with to Screen" dis- permission

play, when the time seemed right to plan a new one, I relied on inspiration, and hit upon a vague idea about words. I left the red carpet and silver foil linings in the cases, as well as many of the glitter stars; added Scrabble, Bananagrams, and Boggle game boards; and pulled books from the collection on words and language, plus an additional dozen thematically appropriate books that had just been donated to the library to add to the display.

Inspired by the modest success of the sticky notes on the standing poster case, I knew I wanted to continue with interactive components for this new display. I debated using poster paper and more sticky notes before settling on dry erase contact paper applied to the glass door of the case. This way, I could include different word games or other activities and change them without much trouble. I also knew that I wanted to include a word jar, so I scrubbed a plastic mayonnaise jar clean, weirdly convinced it would get stolen if I put it out on display. I tied the sticky notepad from the "Page to Screen" display to the rim of the jar and printed a card that explained that we were collecting favorite words and hoped for the best. Another trip to the dollar store yielded rhinestone-studded foam letters to spell "Word Play" for the top of the tall case, a honeycomb bauble garland, and a book of word-fill puzzles. I copied one or two puzzles at a time and put them in a tray labeled "Take One" and, following my spring break vacation, was told that I should have left extras during the week I was gone because people were antsy for new puzzles.
$\mathrm{T} h \mathrm{e}$

most extraordinary thing about the "Word Play" display has been the response to the puzzle on the dry erase paper. For the first game, I posed the question "How many words can we make from the word marshmallow?" and again, started it off myself (shallow, mall) thinking no one would notice or care. I hung a cup with dry erase markers from the case and expected that these would disappear promptly. When I came in the next day, the list had exploded. Over the next few days, my colleagues came to me with stories about how they'd heard odd little bursts of noise from groups of students near the display cases (separated from the reference desk by just a double row of computers) and when they went to investigate, found they were playing the game.

The word jar became increasingly stuffed with hot pink folded notes, to the point it needed emptying, so I typed the list of existing words and added that to the display. Our departmental collective fear that "adult language" would be the odds on favorites in the jar proved entirely without merit. The list also featured some wonderful favorites, including onomatopoeia, anacrusis, and atrocious. Right before spring break, I changed the word game to a words ladder, where you start with a short word (in this case cat) and then change or add one letter to see how far it builds. When I came back to the library ten days later, I found an impressive network of words that matched the spirit if not the letter of the game. Serendipitously, my phone's word-of-the-day app spit out sesquipedalian (meaning "given to using long words") as the day's word on my first day back, so I used that as the word for another "How many words can we make from this word" puzzle, started it with squid and lies and waited to 

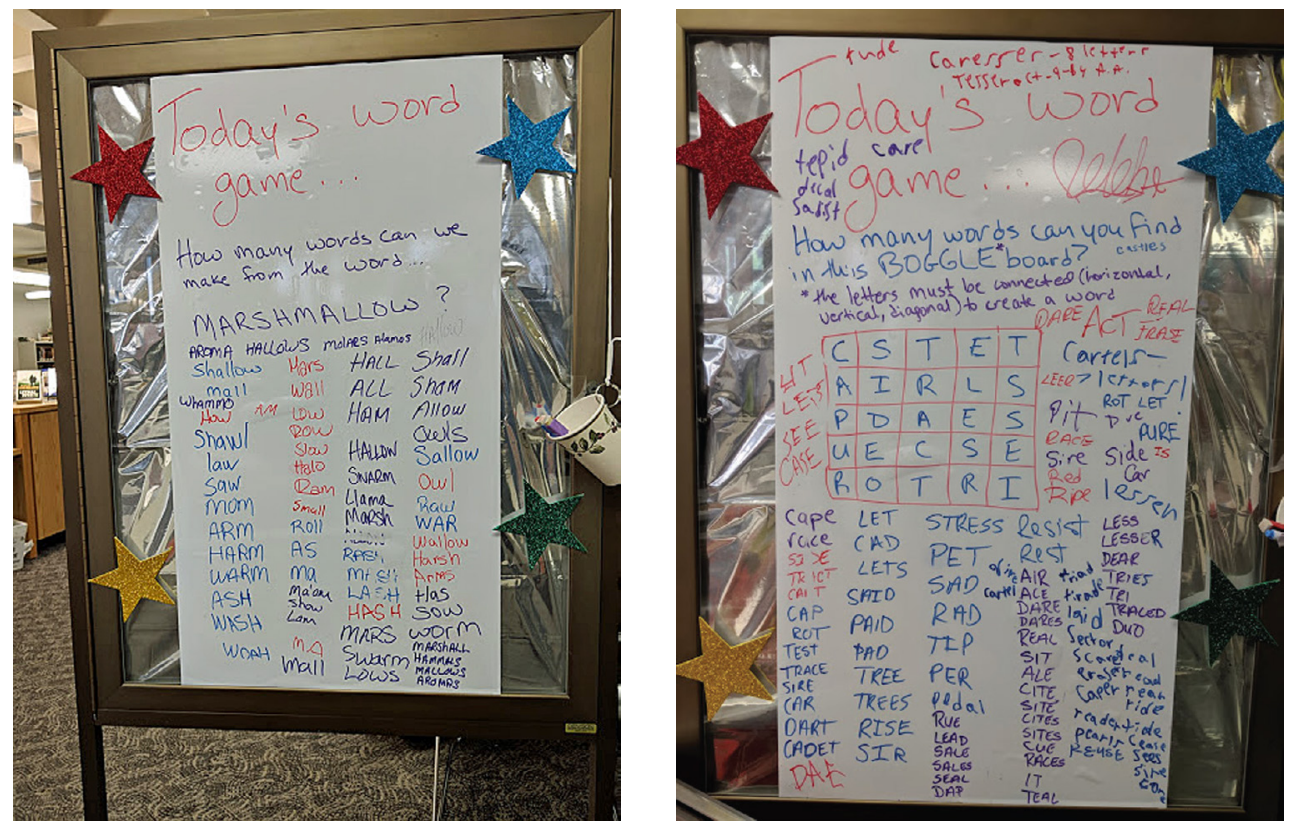

First Word Game (left) and "Boggle" Word Game, QCC Library.

see what would happen. Within less than two days, the students had amassed over 100 words, creating columns and squeezing in additions all around the paper. Looking for something new, I posted a fiveby-five table of letters like a Boggle board and (with a reminder about the rules) queried how many words we could find.

It has been fascinating to watch the way the students interact with the display. There is often something clandestine in how they read the labels or work on the game, typically in pairs or small groups. Not surprisingly, none have approached the faculty or staff to ask about the display (although I have had faculty from other departments and adult residents of the community offer their compliments and enthusiasm), but I have overheard students explaining the display to their peers. They often take cell phone pictures of some of the graphics included in the display (The 100 most beautiful words in the English language or Google's map of the most misspelled words in each state).

The take-aways have been profound in some ways. The interest in these kinds of word games and the modest circulation of the page to screen books have shaken some of the unfortunate stereotypes we hear or hold about community college students-that they don't read, that they're not intellectually curious. That the display has in no way been vandalized has also surprised many in the library, given some of the disruptive student behaviors we sometimes see. The displays' success has also been a powerful reminder that, with a little ingenuity and creativity, it is possible to create engaging and interesting library exhibits that raise interest in library services for very little money. Given the increasing popularity of the displays, my only concern for the future is, what next?

Update: November 2020. When I wrote the last sentence back in September 2019, no one could have guessed that what would soon be next was a devastating global pandemic and widespread lockdowns. Queensborough has been closed and offering fully remote instruction since March 19, 2020. My biggest work worry in those early months working from home was moving information literacy to the virtual world. It wasn't until June, watching the Black Lives Matter protests and reading a report from Duke University libraries on the experiences of their Black students, ${ }^{2}$ that I even considered a virtual display.

Since then, I've completed three. The first, the Black Lives Matter display, ${ }^{3}$ has been featured in the main carousel on the library homepage since June. It includes connections to resources from our databases along with a selection of antiracist books. Our new college president selected the first title for her Presi-

(continues on page 86) 
librarian link in the navigation menu of the LMS course. If there is not a default library link created, the librarian must add this item to the navigation menu. When creating this menu item, it might be good idea to use the librarian's name. Example: "Librarian-Michelle Strasz," so the students see the librarian's name and know exactly who their course librarian is. The librarian menu item can link to a customized subject guide for that course.

3. Next best practice is to get the important due dates for these courses from the syllabus provided. It is recommended that each librarian add these due dates to their calendars, so they can send out a friendly reminder to students when those dates are approaching. Most often, we send emails to the students when the rough draft of their research papers is coming due to ensure they have the resources they need to meet the requirements of the assignment.

4. It is good practice for the librarian to send out an email to the students introducing themselves and explaining what the students can expect from an embedded librarian. We also send emails when we are working weekends. The liaison librarians are scheduled to work two Sunday evenings a semester. This has been a great way to connect to students because we have had many students reply to our emails who want research help.

As COVID-19 moved our traditional and hybrid college courses to fully online for the spring semester, we saw our number of requests for embedded librarianship climb and had more embedded classes this spring than any other spring semester to date. We ended the 2019-2020 fiscal year being embedded into 188 classes, which is up from 101 classes in 2015. Also, the number of departments on campus that have used the embedded librarian program is up from two in 2015 to 14 in 2020.

Having these best practices in place has helped our group of liaison librarians be on the same page and has helped us manage this large influx of embedded courses. This fall semester, the university had a hybrid approach to classes because there were more classes offered online than ever before. Traditional on campus classes were still offered, but the amount of people allowed in the classrooms were greatly reduced. The requests for embedded librarianship soared this fall semester, and we were embedded into 139 courses. We taught library instruction through ZOOM, Microsoft Teams, and Canvas conference. There is still so much unknown about how COVID-19 will affect universities and libraries going forward but for now, many universities will continue offering more online classes. If your university library doesn't have an embedded librarian program, now would be a great time to start.

\section{Notes}

1. Kathy Drewes and Nadine Hoffman, "Academic Embedded Librarianship: An Introduction," Public Services Quarterly 6 (2010): 75-82, accessed May 11, 2020, https://doi.org/10.1080/1522895 9.2010 .498773 .

2. Michelle Strasz, "Online Course Support Librarian Program Assessment 2018," Saginaw Valley State University Library, January 17, 2020, https://librarysubjectguides.svsu.edu/oclassessment2018. $\approx$

\section{("The display's the thing," continued from page 83)}

dent's Book Club from the books in this display. The two others are on elections and voting ${ }^{4}$ and Constitution Day. ${ }^{5}$ While the virtual displays have not seen the kind of traffic and interaction that the in-house displays attracted, they have been an important way to connect critical current events to the library and to students. With no end to the campus closure in sight, I am thinking of how to use our technologies to make online library displays that do even more.

\section{Notes}

1. I should note that the collection development librarian retired at the same time as the display librarian. Our new collection development librarian has been working diligently to build our popular fiction and graphic novels collections, so some variation of these display ideas will be forthcoming.

2. https://dukespace.lib.duke.edu/dspace/handle/10161/20753

3. https://qcc.libguides.com/librarydisplays/ blacklivesmatter

4. https://qcc.libguides.com/librarydisplays/ voting

5. https://qcc.libguides.com/librarydisplays/ constitutionday 2 